\title{
A simple and rapid technique to isolate enriched populations of spermatocytes and spermatids from the immature rat testis
}

\author{
V. Alemán*, R. Trejoł, E. Morales*, P. Hernández-Jáuregui† and \\ G. Delhumeau-Ongay $\ddagger$
}

*Centro de Investigación y de Estudios Avanzados del Instituto Politécnico Nacional, †División de Patologia and $¥$ Sección de Hormonas Proteicas, División de Biología de la Reproducción, Subjefatura de Investigación Básica, Centro Médico Nacional, IMSS, México, D.F.

\begin{abstract}
Summary. A technique was developed to obtain enriched populations of large numbers of primary spermatacytes $(70-81 \%)$ and of spermatids $(75 \%)$ from immature rat testes (21-23 and 38 days old respectively) in a simple and rapid fashion. The cells were nearly all viable and membrane preservation was good. The testicular cells were dispersed by a mild mechanical treatment combined with an incubation with purified collagenase, and the cell populations were separated by centrifugation in a discontinuous dextran gradient in a cell culture medium.
\end{abstract}

\section{Introduction}

The metabolic pattern of the rat testis has been shown to change markedly throughout maturation, e.g. when spermatocytes are converted into spermatids (Tepperman \& Tepperman, 1950; Bishop, 1969; Free, 1970; Delhumeau-Ongay, Trejo-Bayona \& Lara-Vivas, 1973). To be able to study the metabolic changes occurring at these two distinct periods of maturation it seemed important to devise a technique to separate and enrich populations of spermatocytes and spermatids.

The chronological appearance of the different germinal cell types in the immature rat testis has been extensively studied (Clermont \& Peery, 1957; Davis \& Schuetz, 1975). At 23 days of age the tubules include most types of primary spermatocytes, while at 38 days of age spermiogenesis has reached stage 14 (Clermont, 1972). Rat testes at these two ages should therefore be very useful as the starting material for producing enriched populations of spermatocytes and spermatids respectively.

Several procedures for the separation of animal cells (Shortman, 1972) have been used for testicular tissue from various species. For example, velocity sedimentation at unit gravity for several hours in continuous gradients of albumin or ficoll has been used to obtain different germinal cell types from adult (Lam, Furrer \& Bruce, 1970; Go, Vernon \& Fritz, 1971; Meistrich, 1972; Meistrich, Bruce \& Clermont, 1973; Romrell, Bellvé \& Fawcett, 1976) and immature (Meistrich, 1972; Davis \& Schuetz, 1975; Bellvé et al., 1977a) rodents, and velocity sedimentation in isokinetic gradients of ficoll (Pretlow, Scalise \& Weir, 1974), equilibrium density centrifugation in continuous renografin gradients (Meistrich \& Trostle, 1975), centrifugal elutriation in buffered albumin (Grabske, Lake, Gledhill \& Meistrich, 1975) have also been used. In these methods different techniques were used for cell dispersion.

We describe here a technique developed to separate enriched populations of spermatocytes and spermatids. The following features were kept in mind: simplicity, speed, good cell viability and preservation of cell structures, as well as the provision of a sufficiently large number of cells in each population to permit further metabolic or functional studies.

\section{Materials and Methods}

Albino rats of the Wistar-Porton and the Sprague-Dawley strains were used at 23 and 38 days of age. Throughout the experiments the manipulations were carried out at room temperature because cell viability dropped to $30-45 \%$ whenever temperatures above $33^{\circ} \mathrm{C}$ or below $15^{\circ} \mathrm{C}$ were used. The 
rats were killed by decapitation and exsanguinated and the testes were removed. The method for cell dispersion and separation of the testicular cell populations is outlined in Text-fig. 1.

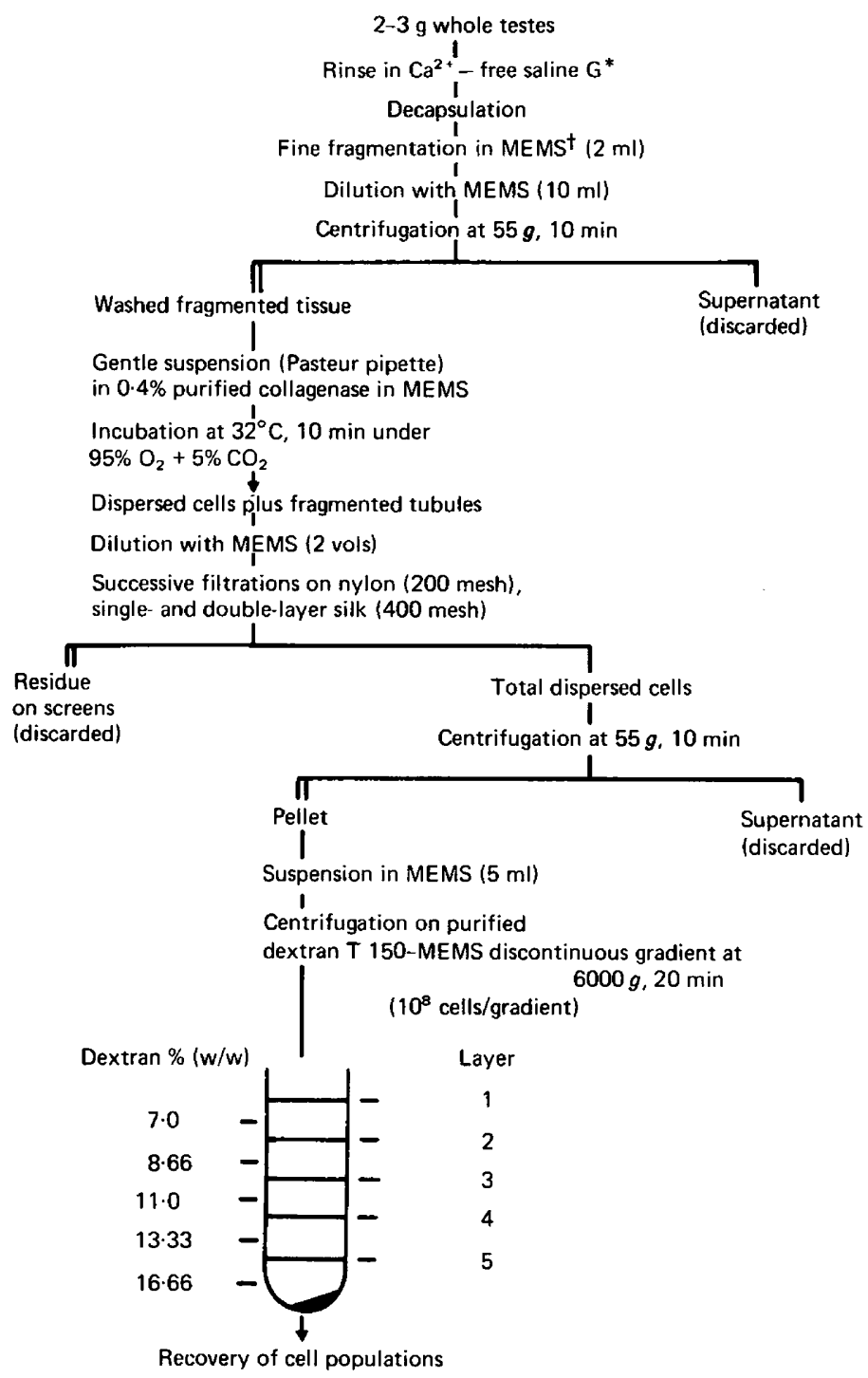

Text-fig. 1. Flow-chart outlining the cell dispersion and separation method for cell populations from the testes of 21-23- and 38-day-old rats.

* $\mathrm{Ca}^{2+}$-free Puck's saline G solution containing $137 \mathrm{~mm}-\mathrm{NaCl}, 5 \cdot 5$ mM-KCl. 1.1 mM- $\mathrm{KH}_{2} \mathrm{PO}_{4}, 1 \cdot 1 \mathrm{~mm}-\mathrm{Na}_{2}-$ $\mathrm{HPO}_{4}, 0.63 \mathrm{~mm}-\mathrm{MgSO}_{4}$ and no glucose.

$\dagger$ Eagle's Minimum Essential Medium (Gibco) supplemented with non-essential amino acids and $1 \%$ previously dialysed and freeze-dried fetal calf serum, $\mathrm{pH} 7 \cdot 2-7 \cdot 4$.

Dispersion. Various enzymes were dissolved in Eagle's Minimum Essential Medium supplemented with non-essential amino acids (Gibco) and $1 \%$ previously dialysed and freeze-dried fetal calf serum, $\mathrm{pH} \mathrm{7.2-7.4} \mathrm{(MEMS),} \mathrm{and} \mathrm{tested} \mathrm{for} \mathrm{their} \mathrm{ability} \mathrm{to} \mathrm{effect} \mathrm{cell} \mathrm{dispersion.} \mathrm{For} 0.05 \%$ doubly crystallized trypsin (Nutritional Biochemicals), a mixture of $0.05 \%$ trypsin and $0.4 \%$ collagenase (form II, Koch-Light Laboratories Ltd, England), and $0.4 \%$ collagenase alone ( $8 \mathrm{mg} / \mathrm{g}$ 
wet tissue), the viabilities were $67 \cdot 5,55 \cdot 3$ and $93-100 \%$ respectively. The $0 \cdot 4 \%$ collagenase maintained this level of viability and good membrane preservation $(100 \%$ of germinal cells with no disruption of membranes as judged by the electron microscope), but if other commercial preparations were used without further purification the germinal cells were damaged ( $30-40 \%$ viability).

Cells were counted in a Levy-Hausser counting chamber. Cell viability was determined by exclusion of $0.5 \%$ trypan blue in a $1: 1(\mathrm{v} / \mathrm{v})$ mixture of MEMS and $\mathrm{Ca}^{2+}$ - and glucose-free Puck's saline $\mathrm{G}$ solution (137 mM-NaCl, $5.5 \mathrm{~mm}-\mathrm{KCl}, 1 \cdot 1 \mathrm{~mm}-\mathrm{KH}_{2} \mathrm{PO}_{4}, 1 \cdot 1 \mathrm{~mm}-\mathrm{Na}_{2} \mathrm{HPO}_{4}$ and $0.63 \mathrm{~mm}-$ $\mathrm{MgSO}_{4}$ ) and also by the ability of the cells to produce lactate aerobically compared with the ability of tissue fragments. Incubations were performed essentially as described by Leiderman (1969), and Leiderman \& Mancini (1968), except that MEMS without fetal calf serum was used as the medium at $33^{\circ} \mathrm{C}$.

Separation. To separate the cell populations, dextran T-150 (Pharmacia, Uppsala) discontinuous density gradients (Text-fig. 1) were prepared. The dextran, previously dialysed and freeze-dried, was dissolved in MEMS, $\mathrm{pH} 7 \cdot 4$. The relative densities of Layers 2, 3, 4 and 5 of the gradients were $1.0384 \pm 0.0018,1.0535 \pm 0.0016,1.0598 \pm 0.0011$ and $1.0816 \pm 0.0014$, respectively $\left(\mathrm{H}_{2} \mathrm{O}=1.000\right)$. Three gradient-containing tubes were centrifuged in each run at room temperature for $20 \mathrm{~min}$.

Identification. The cells were recovered from each layer and those from equivalent layers of the 3 gradients were pooled, diluted with MEMS and centrifuged at $80 \mathrm{~g}$ for $10 \mathrm{~min}$. The cells were then washed with $\mathrm{Ca}^{2+}$ - and glucose-free saline $\mathrm{G}$ solution and centrifuged at $55 \mathrm{~g}$ for 10 min before identification. After fixation overnight in buffered $10 \%$ formaldehyde vapour the cells were stained with PAS-haematoxylin and identified by the criteria of Leblond \& Clermont (1952) and Clermont (1972). The population percentages were calculated from the 1000 to 5000 cells counted for each gradient layer. Data shown are the averages of 4-6 different experiments.

To characterize further the cell distribution among the different layers, DNA content was determined by the modified micromethod of Giles \& Myers (1965) after extraction by the method of Leyva \& Kelley (1974). From these determinations cell recoveries and DNA content per cell were calculated. Diploid cells were assumed to contain 7 pg DNA/cell (Szarski, 1976). Protein was determined in each washed cell population (Hartree, 1972).

Electron microscopy. Cells from each cell population were fixed in buffered glutaraldehyde, post-fixed in $1 \%$ osmium tetroxide, dehydrated in ethanol and embedded in araldite (Glauert \& Glauert, 1958). Sections were obtained on a Reichert $\mathrm{Om} \mathrm{U}_{2}$ ultramicrotome and observed in a Philips EM-300. At least 100 cells from each population were observed and if there was full continuity of the membranes round the cell it was considered to be 'well preserved'. The identification of the cells from their ultrastructural appearance followed that of Burgos, Vitale-Calpe \& Aoki (1970) and Dooher \& Bennet (1973).

\section{Results}

Cell recoveries after the dispersion step are shown in Table 1. The yield per testis was 13 times lower in the younger rats, but it was possible to increase the yield to $29 \times 10^{7}$ cells $/ \mathrm{g}$ tissue if the tubules were resuspended and centrifuged 8 times more with MEMS after the collagenase treatment.

Table 1. Cell populations recovered from rat testes after dispersion

\begin{tabular}{lll}
\hline & \multicolumn{2}{c}{ Age of rat } \\
\cline { 2 - 3 } & \multicolumn{1}{c}{23 days } & \multicolumn{2}{c}{38 days } \\
\hline Wet weight/testis (g) & $0.23 \pm 0.05$ & $0.639 \pm 0.08$ \\
No. of cells/testis & $1.37 \times 10^{7} \pm 0.6 \times 10^{7}$ & $17.24 \times 10^{7} \pm 4.8 \times 10^{7}$ \\
No. of cells/g testis wet weight & $5.8 \times 10^{7} \pm 1.6 \times 10^{7}$ & $29.5 \times 10^{7} \pm 10.9 \times 10^{7}$ \\
\hline
\end{tabular}

Values are the mean of 3-7 experiments \pm standard deviation. 
$\underline{0}$

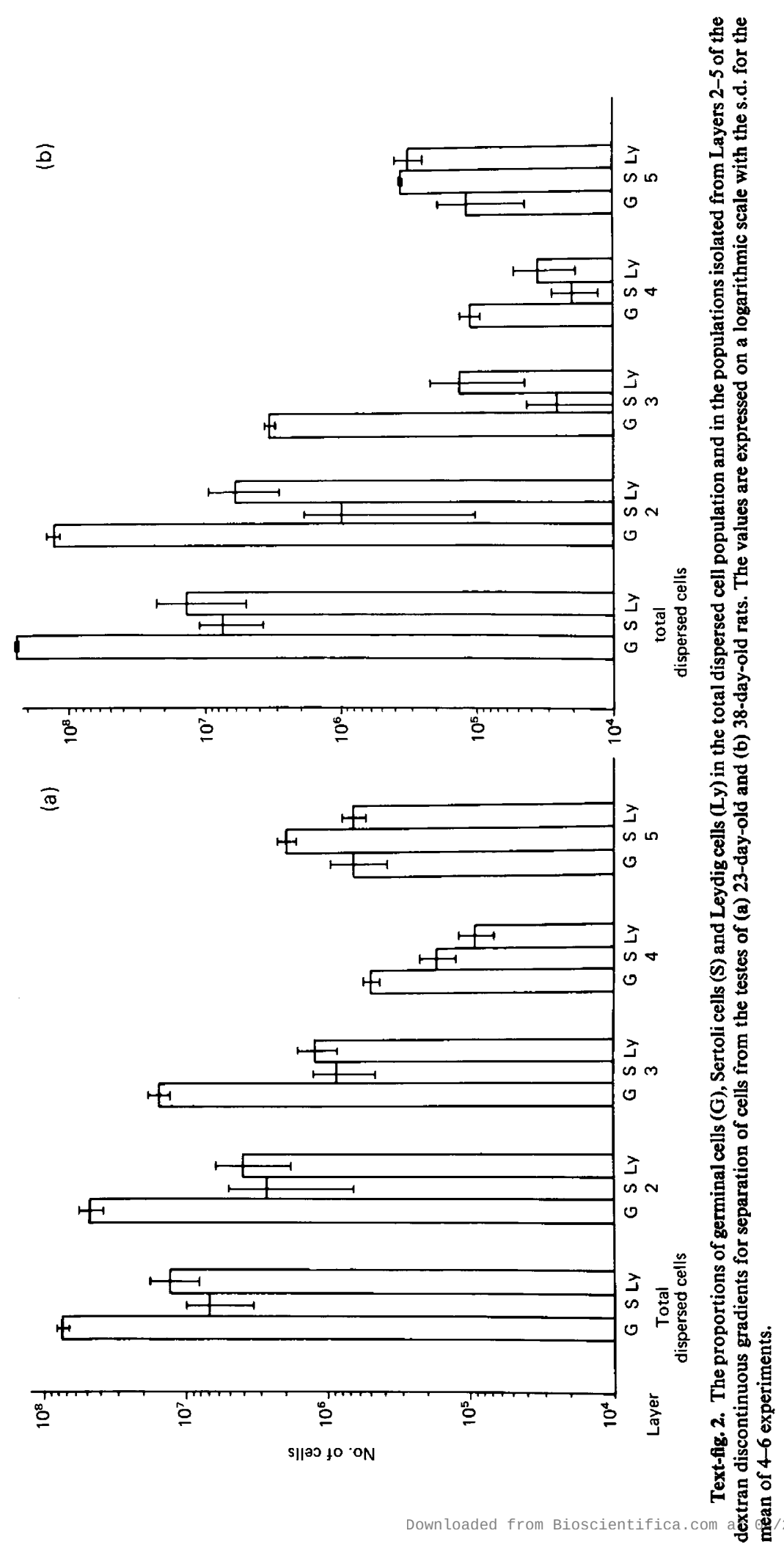




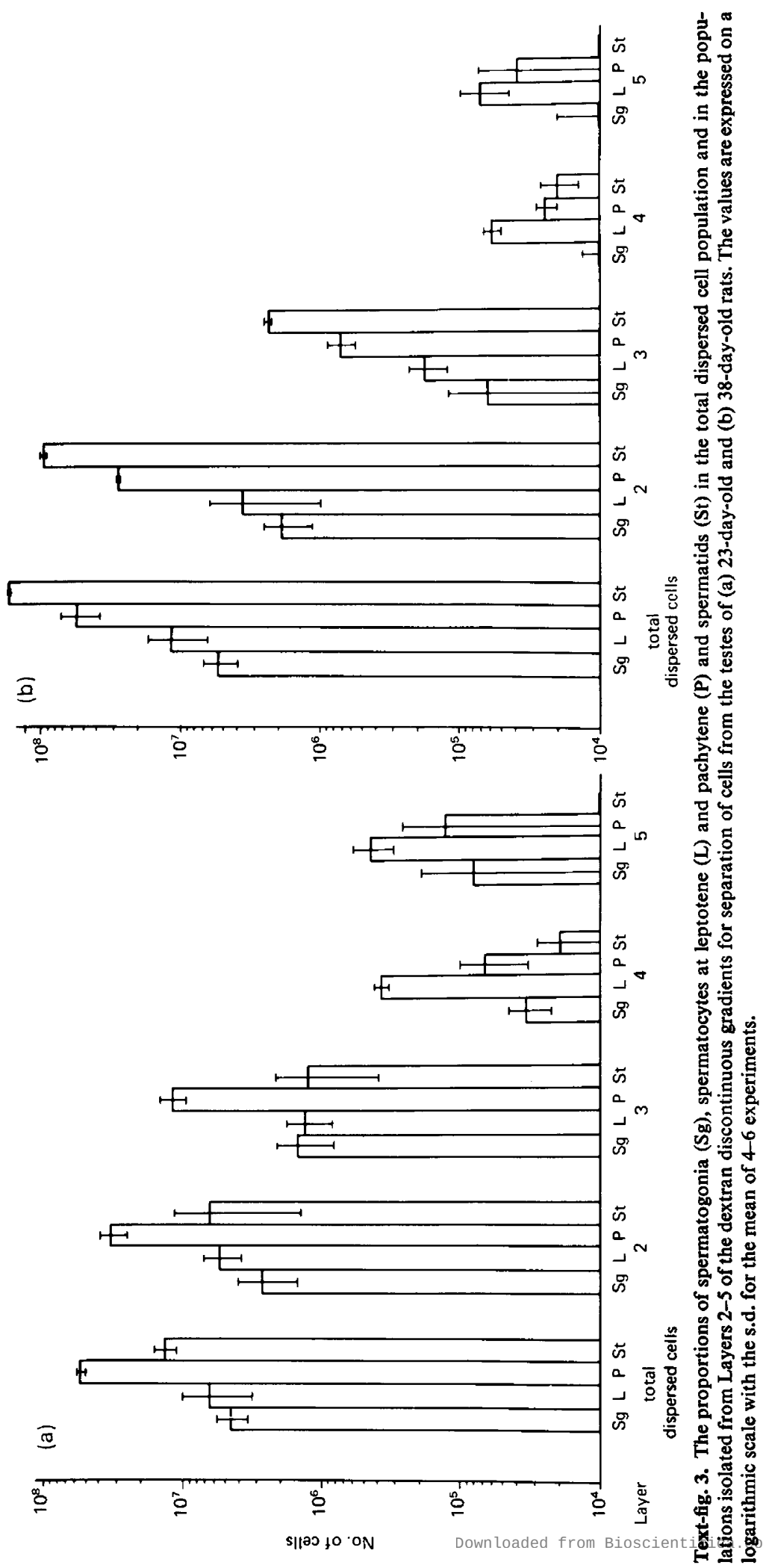


Table 2. Summary of results after separation on discontinuous gradients of dextran of cells from the testes of 23- or 38-day-old rats

\begin{tabular}{|c|c|c|c|c|c|c|c|c|}
\hline \multirow[b]{2}{*}{ Layer } & \multicolumn{2}{|c|}{ Cell no. $\times 10^{7}$} & \multicolumn{2}{|c|}{$\begin{array}{l}\text { Cell recoveries } \\
(\%)\end{array}$} & \multicolumn{2}{|c|}{$\begin{array}{l}\text { Viability } \\
(\%)\end{array}$} & \multicolumn{2}{|c|}{$\begin{array}{l}\text { Protein } \\
(\mathrm{mg})\end{array}$} \\
\hline & 23 days & 38 days & 23 days & 38 days & 23 days & 38 days & 23 days & 38 days \\
\hline \multicolumn{9}{|l|}{ Total dispersed } \\
\hline 2 & $5.377 \pm 1.06$ & $13.66 \pm 2.3$ & $55 \cdot 5$ & 50.0 & 100 & 98 & $7.101 \pm 0.38$ & $15.68 \pm 0.51$ \\
\hline 3 & $1.915 \pm 0.44$ & $0.341 \pm 0.17$ & $19 \cdot 7$ & $1 \cdot 2$ & 93 & 98 & $2.366 \pm 0.71$ & $0.75 \pm 0.17$ \\
\hline 4 & $0.077 \pm 0.05$ & $0.017 \pm 0.002$ & $0 \cdot 8$ & 0.6 & 100 & 97 & $0.2 \pm 0.1$ & $0.09 \pm 0.01$ \\
\hline 5 & $0.338 \pm 0.04$ & $0.079 \pm 0.00$ & 3.5 & $0 \cdot 3$ & 100 & 97 & $0.357 \pm 0.09$ & $0.25 \pm 0.07$ \\
\hline Recovery \% & & & $79 \cdot 55$ & $51 \cdot 18$ & & & $90 \cdot 67$ & $62 \cdot 31$ \\
\hline
\end{tabular}

Values are mean \pm s.đ. for 4-6 experiments.

After the gradient separation, the pellet contained erythrocytes and cell nuclei from damaged cells and Layer 1 contained only a few cells. The details of the cells in the other layers are shown in Table 2. Cell recovery was higher in the 23 - than in the 38-day-old rats and the cells were mainly distributed in Layers 2 and 3 (relative densities above 1.0598). Protein recovery was higher than cell recovery in both groups, but was again better in the younger animals. This observation is consistent with the reported fragility of certain germinal cells (André, 1962).

The recovered cells were metabolically active and total dispersed cells from testes of 38-day-old rats produced aerobically $53 \mathrm{ng}$ lactate $/ \mathrm{h} . \mathrm{mg}$ protein ${ }^{-1}$ compared with the value of $96 \mathrm{ng}$ produced by whole tissue fragments.

\section{EXPLANATION OF PLATES}

\section{PLATE 1}

Photomicrographs of the typical cell populations obtained from the dextran gradients. PAS-haematoxylin.

Fig. 1. Cell population, mostly pachytene primary spermatocytes, from Layer 2 after separation of testis from a 21-day-old rat. $\times 875$.

Fig. 2. Early spermatids, Golgi phase (Stage 1) from Layer 3 after separation of a 38-day-old testis. $\times 3200$.

Fig. 3. Cell population from Layer 2 ( 38 days of age). $P=$ primary spermatocytes. The other cells are mostly spermatids in different stages of development. $\times 850$.

Fig. 4. Sertoli cells from Layer 5 ( 21 days of age) showing the characteristic irregularity and indentation of the nuclei. $\times 3900$.

\section{PLATE 2}

Electron micrographs of the different cell types after separation to show the membrane preservation.

Fig. 5. Late leptotene primary spermatocyte. The nucleus $(N)$ shows a uniform and homogeneous chromatin and chromosomal cores. Groups of mitochondria $(\mathrm{M})$ are present in the cytoplasm. $\times 6630$.

Fig. 6. Pachytene primary spermatocyte. Note condensation of chromatin forming clumps (arrow). The cytoplasm shows groups of mitochondria $(\mathrm{M}) . \times 6450$.

Fig. 7. Step 1 spermatid. The prominent Golgi apparatus $(G)$ has given rise to the pre-acrosomic granule $(\mathrm{Pg})$. Mitochondria (M) are present near the plasma membrane. $\times 7850$.

Fig. 8. Sertoli cell. Note irregularity and indentation of the nucleus (N). The cytoplasm shows numerous cisternae of smooth endoplasmic reticulum (SER). $\times 7950$.

Fig. 9. Leydig cell. In the nucleus $(\mathrm{N})$ there are clumps of chromatin associated with the nuclear membrane. The cytoplasm shows numerous round to ovoid mitochondria (M) with a typical arrangement of cristae and vesicular smooth endoplasmic reticulum (arrow). $\times 8000$. 
PLATE I
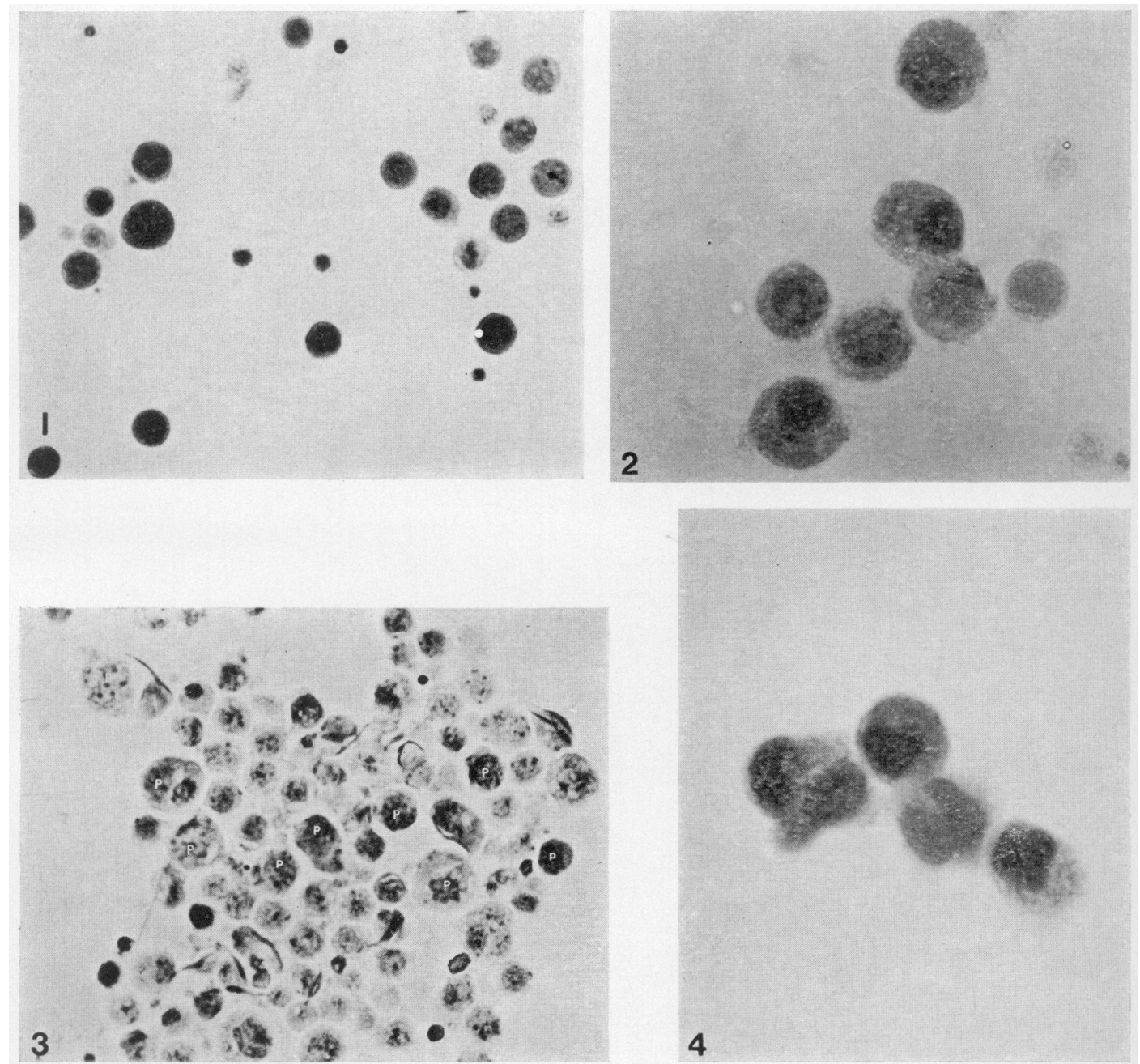

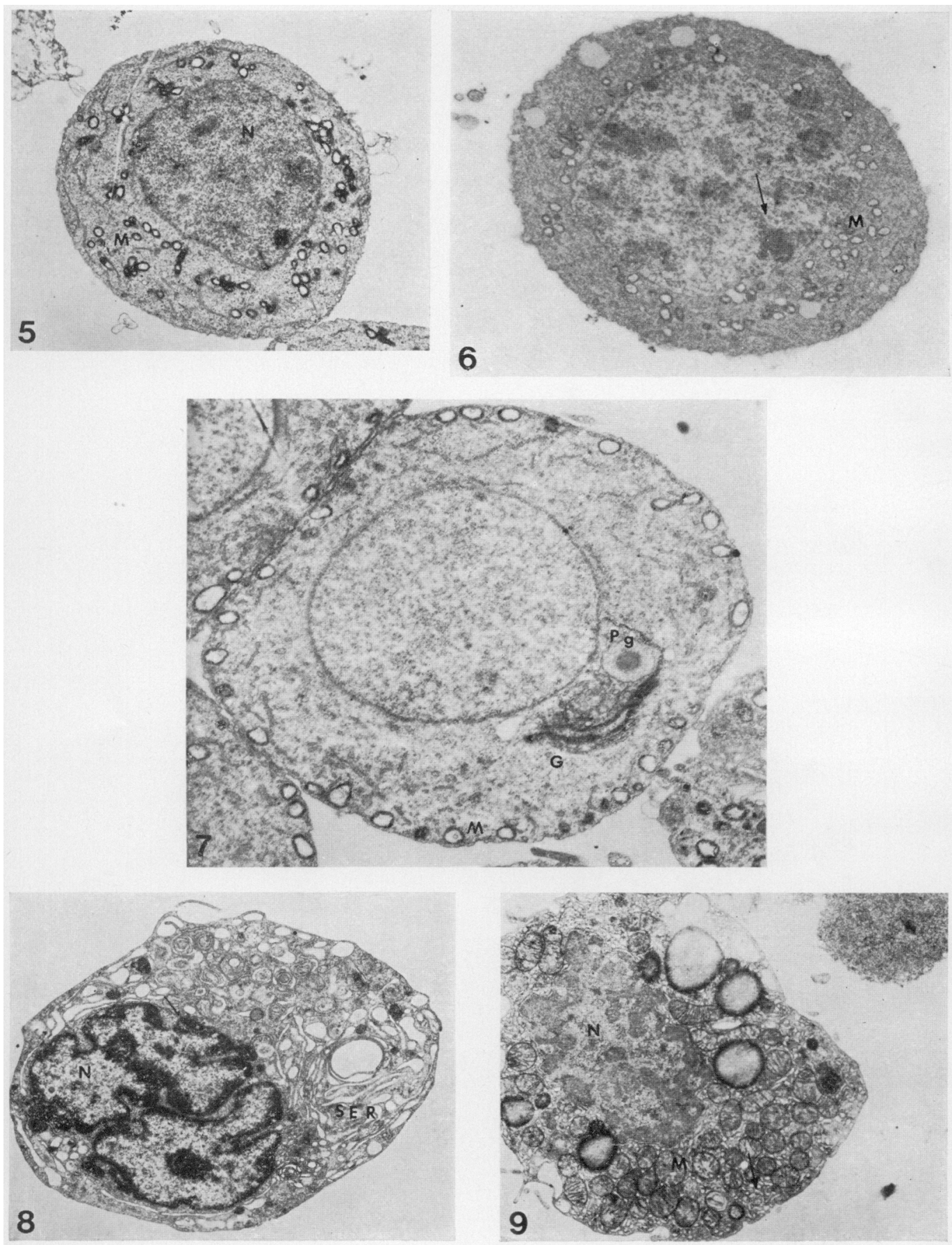


\section{Overall distribution of cells}

The composition of the total dispersed cell populations and that of the cell populations isolated from the different gradient layers is shown in Text-figs 2(a) and 2(b). At 23 days of age most of the germinal cells were recovered in Layers 2 and $3(80 \%)$. Sertoli cells were found mainly in Layers 2 and 5 and were considerably enriched $(60 \%)$ in the latter. Leydig cells were found mainly in Layers 2,3 and 5 but no particular enrichment was observed. At 38 days of age germinal cells were also found mainly in Layers 2 and $3(51 \%)$ and these layers were particularly enriched in germinal cells (98\%). Sertoli cells were present in Layer 5 but the number of cells recovered was one order of magnitude less than that for Layer 5 at 23 days of age. Leydig cells showed a pattern similar to that found in the younger animals.

\section{Distribution of germinal cells}

The distribution of germinal cells in the gradients are shown in Text-figs 3(a) and 3(b). At 23 days of age spermatogonia were mainly found in Layers 2 and 3 but no enrichment of this cell type was obtained. Spermatocytes at leptotene were found in all the layers, but Layer 4 was the most enriched $(49 \%)$. Pachytene spermatocytes (and other primary spermatocytes further developed) were mainly found in Layers 2 and 3, which contained a $70 \%$ enriched population of cells at this stage of differentiation. Some of the 23-day-old rats in certain seasons of the year had early spermatids, but they could be completely avoided if 21-day-old rats were used with exactly the same technique; the enrichment of primary spermatocytes was then raised to $81 \%$. In gradients from 38-day-old rats Layers 2 and 3 contained enriched populations of spermatids ( $75 \%$ ). Primary spermatocytes had a pattern of distribution similar to that of the 23-day-old animals and spermatogonia were practically restricted to Layers 2 and 3.

\section{Structural observations}

Typical photomicrographs of some of the primary spermatocyte and spermatid populations obtained are shown in PI. 1, Figs 1-4. The morphological characterization of the cells in the various cell populations was in accordance with their DNA content, as shown in Table 3. Electron micrographs showing the degree of membrane preservation of the cells are presented in Pl. 2, Figs 5-9. Total dispersed cell populations from 23- and 38-day-old rats showed $100 \%$ preservation of their membrane structures. Very few symplastic formations were observed. In the 23-day-old rats, 68 and $80.2 \%$ of the cells recovered from Layers 2 and 4 respectively had intact membrane structures. The value for Layer 4 in the 38-day-old rats was $87.6 \%$; that for Layer 2 was lower, probably because of the known fragility of spermatids (André, 1962).

Table 3. DNA content ( $\mathrm{pg} /$ cell) of rat testicular cells in the various gradient layers after separation

\begin{tabular}{lcrrcc}
\hline & & \multicolumn{4}{c}{ Layer } \\
\cline { 2 - 6 } & $\begin{array}{c}\text { Age } \\
\text { (days) }\end{array}$ & \multicolumn{1}{c}{2} & \multicolumn{1}{c}{3} & 4 & 5 \\
\hline Experimental & 23 & 12.7 & 12.2 & 11.0 & 8.0 \\
Theoretical & 38 & 5.0 & 7.0 & & \\
& 23 & 12.1 & 11.7 & 11.1 & 8.1 \\
& 38 & 4.1 & 6.7 & & \\
\hline
\end{tabular}

Experimental values: DNA/no. of cells recovered.

Theoretical values: calculated from the percentage of each cell type in the population recovered from the layer, assuming $\mathrm{n}=3.5 \mathrm{pg}$ DNA; and spermatids $=\mathrm{n}$, spermatogonia, Sertoli cells and Leydig cells $=2 n$ and spermatocytes $=4 n$.

When this work was almost completed dextran T-500 (Pharmacia, Uppsala) became available and was tested. Results were essentially identical under the same conditions, except that the gradients were centrifuged for $30 \mathrm{~min}$ (instead of $20 \mathrm{~min}$ ) for testes from 38-day-old rats. 


\section{Discussion}

The technique described here was developed to obtain enriched populations of spermatocytes and of spermatids in enough quantities and in a good enough condition of preservation to permit study of the metabolic differences between these two distinct stages of differentiation and advantage was taken of the chronological appearance of the different germinal cell types in rat testes during maturation. For example, at 21-23 days of age all types of primary spermatocytes are present and represent the main cell population, further enrichment occurring in Layers 2 and 3, and at 38 days, when spermiogenesis has attained stage 14 (Clermont, 1972), spermatids are obtained in the enriched populations. If older rats are used the flagella and the large numbers of spermatozoa prevent reproducible separation of the other cell types.

To perform metabolic studies on isolated cells both their number and integrity of cell structures are important factors. Previous cell separation methods described in the literature have resulted in some germinal cell populations with a lower contamination by other cell types (Meistrich \& Trostle, 1975; Davis \& Schuetz, 1975; Romrell et al., 1976), but these cell populations are often highly diluted and/or the number of cells recovered is not high enough for particular metabolic studies. Electron microscopy of the germinal cell preparations has not always been included (Lam et al., 1970; Go et al., 1971; Meistrich, 1972; Meistrich et al., 1973; Pretlow et al., 1974; Meistrich \& Trostle, 1975; Davis \& Schuetz, 1975; Grabske et al., 1975), and it is therefore difficult to compare the degree of preservation of the cellular structures with the various techniques.

Romrell et al. (1976), Bellvé, Millette, Bhatnagar \& O’Brien (1977b) and Barcellona \& Meistrich (1977) have examined the integrity of isolated mouse testicular cells. Their results seem comparable to those of the present study but no mention was made of the percentage of cells showing good membrane preservation. By our technique we could obtain, within $3 \mathrm{~h}$, over $58 \times 10^{6}$ well preserved primary spermatocytes from a population of $72 \times 10^{6}$ cells (Layer $2+$ Layer 3 of the gradients from 21-23-day-old rats) or $105 \times 10^{6}$ spermatids from a population of $140 \times 10^{6}$ cells (Layer $2+$ Layer 3 of the gradients from 38-day -old rats).

The contamination of each cell population by the other cell types present was the most serious limitation of the technique and should be taken into consideration. Further purification of the germinal cell populations may perhaps be obtained by a combination with another sequential discontinuous gradient or with an elutriation centrifugation, such as that described by Grabske et al. (1975).

This work was partly supported by a grant from the Ford Foundation. We thank Mrs Elodia Cruz-Lavin for skillful technical assistance and Mrs L. Ponce de León and Mrs C. García for secretarial help.

\section{References}

ANDré, J. (1962) Contribution à la connaissance du chondriome. Etude de ses modifications ultrastructurales pendant la spermatogenése. J. Ultrastruct. Res., Suppl. 3, 1-185.

Barcellona, W. J. \& Meistrich, J.L. (1977) Ultrastructural integrity of mouse testicular cells separated by velocity sedimentation. $J$. Reprod. Fert. 50, 61-68.

Bellvé, A.R., Cavicchia, J.C., Millette, C.F.; O'Brien, D.A., Bhatnagar, Y.M. \& Dym., M. (1977a) Spermatogenic cells of prepuberal mouse: isolation and morphological characterization. $J$. Cell. Biol 74, 68-85.

Bellve, A.R., Millette, C.F. Bhatnagar, Y.M. \& O'BrIEN, D.A. (1977b) Dissociation of mouse testis and characterization of isolated spermatogenic cells. J. Histochem. Cytochem. 25, 480-494.
BisHop, D.W. (1969) Testicular enzymes as fingerprints in the study of spermatogenesis. In Reproduction and Sexual Behavior, pp. 261-286. Ed. M. Diamond. Indiana University Press.

Burgos, M.H., Vitale-CalPe, R. \& AOKI, A. (1970) Fine structure of the testis and its functional significance. In The Testis, Vol. I, pp. 551-577. Eds A. D. Johnson, W. R. Gomes \& N. L. VanDemark. Academic Press, New York.

Clermont, Y. (1972) Kinetics of spermatogenesis in mammals: seminiferous epithelium cycle and spermatogonial renewal. Physiol. Rev. 52, 198236.

Clermont, Y. \& Perey, B. (1957) Quantitative study of the cell population of the seminiferous tubules in immature rats. Am J. Anat. 100, 241-267. 
Davis, J.C. \& Schuetz, A.W. (1975) Separation of germinal cells from immature rat testes by sedimentation at unit gravity. Expl Cell Res. 91, 79-86.

Delhumeau-Ongay, G., Trejo-Bayona, R. \& LaraVIVAS, L. (1973) Changes of $\left(\mathrm{Ca}^{2+}-\mathrm{Mg}^{2+}\right)$-adenosinetriphosphatase activity in rat testis throughout maturation. J. Reprod. Fert. 33, 513-517.

Dooher, G.B. \& BenNeTt, D. (1973) Fine structural observations on the development of the sperm head in the mouse. Am. J. Anat. 136, 339-361.

FreE, M.J. (1970) Carbohydrate metabolism in the testis. In The Testis, Vol. II, pp. 125-192. Eds A.D. Johnson, W. R. Gomes \& N. L. VanDemark. Academic Press, New York.

Giles, K.W. \& MYers, A. (1965) An improved diphenylamine method for the estimation of deoxyribonucleic acid. Nature, Lond. 206, 93.

Glauert, A.M. \& Glauert, R.H. (1958) Araidite as an embedding medium for electron microscopy. $J$. Biophys. Biochem. Cytol. 4, 191-200.

Go, V.L.W., VernoN, R.G. \& FrITZ, I.B. (1971) Studies on spermatogenesis in rats. I. Application of sedimentation velocity technique to an investigation of spermatogenesis. Can. J. Biochem. 49, 753-760.

Grabske, R.J., Lake, S., Gledhill, B.L. \& Meistrich, M.L. (1975) Centrifugal elutriation: separation of spermatogenic cells on the basis of sedimentation velocity. J. cell. Physiol. 86, 177-190.

HarTree, E.F. (1972) Determination of protein: a modification of the Lowry method that gives a linear photometric response. Analyt. Biochem. 48 $422-427$

LAM, D.M.K., Furrer, R. \& Bruce, W.R. (1970) The separation, physical characterization and differentiation kinetics of spermatogonial cells of the mouse. Proc. natn. Acad. Sci. U.S.A. 65, 192-199.

Leblond, C.P. \& Clermont, Y. (1952) Spermiogenesis of rat, mouse, hamster and guinea pig as revealed by the periodic acid-fuschsin sulfurous acid technique. Am. J. Anat. 90, 167-215.
LeIderman, B. (1969) Consumo de oxigeno y producción de ácido láctico de células germinales aisladas "in vitro" de testículo de rata. Revta Soc. argent. Biol. 45, 57-63.

Leiderman, B. \& Mancini, R.E. (1968) Aerobic and anaerobic lactate production in the prepuberal and adult rat testis. Proc. Soc. exp. Biol. Med. 128, 818821.

Leyva, A., JR \& Kelley, W.N. (1974) Measurement of DNA in cultured human cells. Analyt. Biochem. 62, 173-179.

Meistrich, M.L. (1972) Separation of mouse spermatogenic cells by velocity sedimentation. $J$. cell. Physiol. 80, 299-312.

Meistrich, M.L. \& Trostle, P.K. (1975) Separation of mouse testis cells by equilibrium density centrifugation in renografin gradients. Expl Cell Res. 92, 231244.

Meistrich, M.L., Bruce, W.R. \& Clermont, Y. (1973) Cellular composition of fractions of mouse testis cells following velocity sedimentation separation. Expl Cell Res. 79, 213-227.

Pretlow, T.G., II, Scalise, M.M. \& Weir, E.E. (1974) Separation of hamster testicular cells in successive stages of differentiation by velocity sedimentation in isokinetic gradient of ficoll in tissue culture medium. Am.J. Path. 74, 83-94.

Romrell, L.J., Bellvé A.R. \& FAWCETt, D.W. (1976) Separation of mouse spermatogenic cells by sedimentation velocity: a morphological characterization. Devl Biol 49, 119-131.

Shortman, K. (1972) Physical procedures for the separation of animal cells. A. Rev. Biophys. Bioeng. 1, 93-130.

SzarSKI, H. (1976) Cell size and nuclear DNA content in vertebrates. Int. Rev. Cytol. 44, 93-111.

Tepperman, H.M. \& Tepperman, J. (1950) Glucose utilization in vitro by normal adult, immature and cryptorchid testis. Endocrinology 47, 459.

Received 8 November 1977 